\title{
Glaudesnio bendradarbiavimo ES perspektyvos ir pasekmès Lietuvai
}

\begin{abstract}
Šiame straipsnyje aptariama keletas su glaudesniu bendradarbiavimu ir jo potencialiu poveikiu naujoms narems (pirmiausia Lietuvai) susijusių klausimų. Pirmiausia aptariama glaudesnio bendradarbiavimo sampratos raida, parodant, jog siekis suderinti skirtingų preferencijų ir galimybių valstybių norą integruotis yra būdingas visai pokario Europos istorijai. Pristatomi pagrindiniai glaudesnio bendradarbiavimo formalizavimo ES sutartyje motyvai ir aplinkybès, susiklosčiusios per pastaraji dešimtmetį. Po to aptariamos konkrečios glaudesnio bendradarbiavimo nuostatos, ịtvirtintos ES sutartyje. Skirtingi motyvai bei lūkesčiai, susiję su glaudesniu bendradarbiavimu ES viduje bei dèmesys jam diskusijose dèl Europos ateities, suteikia pagrindo teigti, jog formaliu (ir neformalių) glaudesnio bendradarbiavimo iniciatyvu pletra ir igyvendinimas yra vienas iš svarbiausiu klausimų, nuo kurio priklausys ir tolesnè ES raida po jos plètros, ir narystės Sajungoje teikiama nauda Lietuvai ir kitoms narems. Tai susiję ir su galimomis tarpvyriausybinèmis koalicijomis ES po plètros, kurios detaliai analizuojamos straipsnyje, bei su jų tikètinu stabilumu. Galiausiai ịvertinamos glaudesnio bendradarbiavimo perspektyvos ES po jos plètros ir su tuo susiję iššǔkiai Lietuvai.
\end{abstract}

\section{Ivadas}

2004 m. gegužès mėn. ES narèmis taps aštuonios Vidurio ir Rytų Europos valstybès, taip pat Kipras ir Malta. Tikètina, jog dar po keleto metų prie ES prisijungs Bulgarija, Rumunija, Kroatija, o dar vèliau - ir kitos Balkanų šalys (ir galbūt Turkija). Vienas pagrindinių šios Europos Sajungos plètros bruožų - dèl kaip niekada smarkiai padidėjusio valstybių narių skaičiaus išaugsianti ịvairove tarp ES valstybių.

ES yra valstybių klubas, kurio veikla yra pagrịsta vieningomis institucijomis (Europos Komisija, Europos Teisingumo Teismas ir kt.) bei visiems bendromis teisès normomis (ang. acquis communautaire). Nenuostabu, jog, dar prieš prasidedant deryboms su Vidurio ir Rytų Europos šalimis, kai kurie ES institucijų bei valstybiu narių vadovai pradėjo kalbèti apie poreikị sukurti schemas po plètros išaugusios įvairovès Sajungoje valdymui, sudarant formalią galimybę grupėms giliau integruotis, o norinčioms ir galinčioms valstybėms narėms sparčiau tarpusavyje plètoti naujus integracijos projektus. Šie svarstymai dar labiau suintensyvèjo prasidèjus diskusijai dèl Europos ateities, o pagrindinị vaidmenį, siūlant diferencijuotos integracijos vizi-

"Doc., dr. Ramūnas Vilpišauskas - Vilniaus universiteto Tarptautinių santykių ir politikos mokslu instituto docentas. Adresas: Vokiečių 10, 01130 Vilnius, tel. 8-5-2514130, e-paštas:

ramunas@lrinka.It 
jas, vaidino Vokietijos ir Prancūzijos politikai ${ }^{1}$. Nors ir ịvardinama skirtingai - kaip „gravitacijos centras“(Joschka Fischer), kaip ,,avangardas“ (Jacques Delors) ar kaip „pionieriu grupe““(Jacques Chirac) - tokia „klubas klubo viduje“ galimybè yra laikoma vienu iš pagrindinių dilemos tarp išaugusios įvairovès ir siekio išlaikyti ES funkcionalia organizacija (ir apsisaugoti nuo galimo integracijos sulètèjimo po plètros) sprendimo būdų.

Glaudesnio (arba sustiprinto) bendradarbiavimo (pastaraisiais metais nusistovi būtent tokia šio institucinio mechanizmo, suteikiančio pagrindą diferencijuotai integracijai ES viduje, formuluotė) motyvai ir pasekmès gali būti interpretuojami gana ịvairiai. Kai kuriems ES politikams ir ekspertams glaudesnio bendradarbiavimo galimybės formalizavimas Amsterdamo sutartyje ir tolesnis jo įtvirtinimas Nicos sutartyje bei dabar svarstomoje ES konstitucijoje yra būtinas, norint apsisaugoti nuo ES fragmentacijos ir užtikrinti institucines galimybes efektyviam ES funkcionavimui. Kitiems tai - galimybė bendradarbiauti glaudžiame (senujų) ES valstybių narių būrelyje, kurio netrikdytų prie „senosios šeimos“ ipročių nepripratusios naujosios narès. Pastarasis motyvas dažniausiai priskiriamas Prancūzijos ir Vokietijos politikams, kurių „dvišalis motoras“ dažnai būdavo pagrindinė varomoji jèga už daugelio integracijos projektų nuo pat Bendrijų sukūrimo. Formalizuotas glaudesnis bendradarbiavimas suteikia galimybę tokias neformaliai užmegztas dvišales iniciatyvas plètoti, naudojantis formaliais instituciniais mechanizmais. Tačiau reikia pastebèti,jog dabartine jo formuluotė (ypač atvirumas prisijungti visoms norinčioms dalyvauti šalims bei minimalaus dalyvaujančiujų skaičiaus nustatymas) atspindi kompromisą tarp atsargiai ị diferenciaciją žiūrinčių valstybių narių, Europos Bendrijos metodo išlaikymu ir vientisomis struktūromis (įskaitant ir savo vaidmenị) suinteresuotos Europos Komisijos bei Prancūzijos ir Vokietijos (ir keleto kitų šalių), susirūpinusiu galimybe išlaikyti integracijos tempą ir nusistovëjusius koordinavimo įpročius po ES plètros.

Kita vertus, kai kurios dabartinės ES ir ypač būsimosios jos narès, îskaitant ir Lietuvą, gana atsargiai vertina glaudesnio bendradarbiavimo sampratą. Nors formaliai glaudžiau bendradarbiauti gali bet kokia norinti ir galinti būti naujo integracijos projekto nare valstybè, tačiau dèl politinių preferencijų, ekonominių charakteristikų ir kitokių skirtumų dalyvavimas naujuose integracijos projektuose neišvengiamai sukurtų dilemą tarp nacionalinių interesų bei dalyvavimo integracijoje vien dèl noro nelikti politinejje periferijoje. Kitaip sakant, būtent dèl tų pačių priežasčių, dèl kurių Prancūzija, Vokietija ar Beniliukso šalys norètų glaudžiau bendradarbiauti mokesčiu, saugumo ir gynybos politikos ar kitose srityse, kitoms šalims (Didžiajai Britanijai, Lietuvai ir kt.) jis gali sukurti grèsmę būti paliktoms už sprendimus priimančio rato ribų. Lietuvoje ir kitose stojančiose šalyse ši grèsmè įvardijama antrarūšès narès statusu.

Skirtingi motyvai bei lūkesčiai, susiję su glaudesniu bendradarbiavimu ES, bei dèmesys bendradarbiavimui diskusijose dèl Europos ateities suteikia pagrindo

\footnotetext{
${ }^{1}$ Diskusijų apie naują ES valstybių narių branduolị Sajungoje, kurị sudarytų labiausiai tolesnę integraciją palaikančios šalys (greičiausiai EB sukūrusios šešios šalys), pradžia laikomas $1994 \mathrm{~m}$. rugsejji paskelbtas Vokietijos Bundestago narių Schauble ir Lamers paskelbtas tekstas „Apmąstymai apie Europą“. Vèliau šios diskusijos buvo tęsiamos, pradejus svarstymus apie Europos ateitị.
} 
teigti, jog formalių (ir neformalių) glaudesnio bendradarbiavimo iniciatyvų plètojimas ir iggyvendinimas yra vienas iš svarbiausių klausimų, nuo kurio priklausys ir tolesnè ES raida po jos plètros, ir narystès Sajungoje teikiama nauda Lietuvai ir kitoms narems. Šiame straipsnyje aptariama keletas su glaudesniu bendradarbiavimu ir jo potencialiu poveikiu naujoms narems (pirmiausia Lietuvai) susijusių klausimų. Pirma, aptariama glaudesnio bendradarbiavimo sampratos raida, parodant, jog siekis suderinti skirtingų preferencijų ir galimybių valstybių norą integruotis yra būdingas visai pokario Europos istorijai. Pristatomi pagrindiniai glaudesnio bendradarbiavimo formalizavimo ES sutartyje motyvai ir aplinkybès, susiklosčiusios per pastarajį dešimtmetị. Po to aptariamos konkrečios glaudesnio bendradarbiavimo nuostatos, ittvirtintos ES sutartyje. Galiausiai yra įvertinamos glaudesnio bendradarbiavimo perspektyvos ES po jos plètros ir su tuo susiję iššūkiai Lietuvai.

Prieš pereinant prie pirmojo klausimo, reikia pateikti keletą metodologiniu pastabų. Pati temos formuluotè sąlygoja tai, jog čia bus kalbama daugiausia apie bendradarbiavima ES tarp vyriausybių. Glaudesnis bendradarbiavimas gali vykti tik tarp valstybių, o ne regionų, interesų grupių ar kitokių institucijų ir yra grindžiamas nacionalinių preferencijų ir gebejjimų panašumais (tarp norinčiu jị plètoti šalių) ir skirtumais (tarp inicijuojančių naują integracijos projektą ir liekančių už jo ribų) ${ }^{2}$. Kitaip sakant, politinė dinamika ES yra vertinama iš tarptautinių santykių disciplinų perspektyvų.

Nagrinëjant sąlygas glaudesniam bendradarbiavimui ir jo pasekmes nedalyvaujančioms šalims svarbiausiu klausimu tampa klausimas apie tai, kas lemia valstybių preferencijas plètoti arba susilaikyti nuo tolesnès (gilesnès) integracijos bei jų gebėjimus tai daryti. Tarptautinių santykių ir politinės ekonomijos literatūroje galima rasti keletą populiarių požiūrių į nacionalinių preferencijų formavimą. Vieni akcentuoja struktūrinius tarptautinius veiksnius - šalies dydị, ekonominio išsivystymo lygị, istorinę patirtį ir pan. Kiti pagrindinị dèmesį skiria tokiems šalių vidaus politikos veiksniams, kaip elito ir jo dominuojančios idejos, geriausiai organizuotu interesų grupių spaudimas ir jų sąveika su perrinkimu besirūpinančiais politikais ar ekspertų dominavimas, formuojant nacionalinius interesus. Šie klausimai plačiau bus aptarti paskutineje dalyje kalbant apie galimas koalicijas ES viduje po jos plètros bei Lietuvos interesus, aptariant įvairius koalicijų formavimąsi skatinančius veiksnius.

\section{Skirtumų valdymas besiintegruojančioje Europoje}

Dažnai manoma, jog diskusijos apie glaudesnị bendradarbiavimą prasidejjo pastarajị dešimtmetị, kilus klausimams dèl Ekonominès ir pinigų sajungos (tolesnio ES gilinimo) bei Vidurio ir Rytų Europos šalių narystès (tolesnès ES plètros). Vis dèlto skirtingas Europos šalių entuziazmo bei gebejjimo integruotis laipsnis ir su juo susijęs siekis ieškoti lanksčių bendradarbiavimo sprendimų pastebimas nuo pirmujų

${ }^{2}$ Kaip yra pastebeję̨s vienas ekspertas, ,glaudesnis bendradarbiavimas tam tikra prasme iš naujo ittvirtina valstybes kaip monolitinius veikejus“" (De Areilza J. M., Enhanced Cooperation in the Treaty of Amsterdam: Some Critical Comments, Jean Monnet Center Working Paper, 1998, p. 5). 
žingsnių kuriant Europos Bendrijas. Kaip pastebi H. Wallace, „Vakarų Europos istorija yra nusèta pastangų sukurti priemones giliau integruotis toms vyriausybėms, kurios linkusios žengti pirmyn, nei dvejojančioms“"3. Pagrindiniais pirmaisiais tokiu pastangų pavyzdžiais galima laikyti Europos anglių ir plieno bendrijos, o vèliau ir kitų dviejų bendrijų sukūrimą tarp šešių integruotis linkusių šalių bei véliau EFTA grupès suformavimą tarp ne itin entuziastingai integracijos atžvilgiu nusiteikusių valstybių.

Tiesa, šiuo atžvilgiu tuometinė Vidurio ir Rytų Europa skyrèsi nuo Vakarų tuo, jog viena iš sąlygų - šių šalių gebejimas integruotis su Vakarų Europos šalimis buvo visiškai apribota dèl išorinių politinių priežasčių. Iš dalies dèl tų pačių Europos padalijimą sąlygojusių priežasčių kai kurios neutralios Europos šalys (Suomija, Austrija) taip pat negalëjo laisvai pasirinkti dalyvauti po II Pasaulinio karo kuriamuose bendradarbiavimo projektuose - Europos Bendrijose, NATO ir Vakarų Europos Sajungoje. Tik pasikeitus tarptautinei padèčiai, po Šaltojo karo pabaigos, galima prasmingai kalbèti apie lankstaus bendradarbiavimo klausimus visoje Europoje (ir būtent dèl to kai kuriose Vidurio ir Rytu Europos šalyse taip jautriai reaguojama i Prancūzijos ir kitų „senųjų narių“ politikų svarstymus apie glaudesnį bendradarbiavimą, kuris, manoma, gali tapti nauja galios sutelkimo priemone ir nauja kliūtimi visai neseniai atkurtiems lygiaverčiams santykiams).

Vis dèlto Vakarų Europos šalių grupeje, nors ir geografiškai ribotoje, glaudesnio formalaus ir neformalaus integravimosi patirtis yra gana ilga. Ir ekonominès integracijos, ir saugumo bei karinio bendradarbiavimo srityse nuolatos buvo daugiau ar mažiau entuziastingai integracijos atžvilgiu nusiteikusių šalių. Tai atspindejo ir formali narystè skirtingose organizacijose, ir neformalios naujų projektų iniciatyvos tarp keleto šalių, kurias dažnai po to perimdavo platesnès šalių grupés. Tik nuo praejjusio dešimtmečio pradžios ES pradejo aiškiai dominuoti Europoje kaip pagrindinè funkcinè organizacija, kurios narèmis galiausiai gali tapti didžioji dauguma žemyno valstybių. Kitaip sakant, tik visai neseniai ES pradèta laikyti ir geografiškai, ir funkciškai pagrindine Europos organizacija. Tad, galima sakyti, klausimas apie institucinę Europą, kurią sudare įvairios narystès atžvilgiu persidengiančios Europos ir transatlantinès organizacijos, pavirto klausimu apie glaudesnį bendradarbiavimą gausesnèje ir ịvairesnèje ES. Kaip paradoksaliai tai beskambètų, tačiau būtent ES sẻkmè jos narystès patrauklumo atžvilgiu sukūrè sąlygas diskusijoms apie glaudesni bendradarbiavimą jos viduje, kuris, kaip jau minèta, gali būti interpretuojamas ir kaip dalies narystės privalumų naujoms narėms atitolinimas.

Diskusijos apie lanksčios (diferencijuotos) integracijos metodus Europoje (ir laipsniškai pačioje ES) ypač suintensyvejjo praejjusio dešimtmečio pirmoje pusëje. Tuo metu skirtingų valstybių narių atstovai bei akademikai aptarinėjo įvairias lankstaus bendradarbiavimo formas - Europa a la carte, „,skirtingų greičių“ Europa ir „varijuojančios geometrijos“ Europa. Šios vizijos, dar apibūdinamos ịvairiomis kitomis metaforomis, nors ir dažnai painiojamos, reiške gana skirtingus dalykus: galimybę atskiroms valstybėms narèms pasirinkti ịvairius integracijos projektus, sutariant

${ }^{3}$ Wallace H., „Flexibility: A Tool of Integration or a Restraint on Disintegration?“ in Neunreither K., Wiener A., eds., European Integration after Amsterdam, Oxford: Oxford University Press, 2000, p. 175. 
dèl minimalaus visiems bendrų tikslų skaičiaus (pavyzdžiui, vidaus rinkos), lanksti integracija, kai galinčiu ir norinčių šalių grupe integruojasi sparčiau už kitas, drauge paliekant galimybę kitoms prisijungti prie jų (pavyzdžiui, Ekonominè ir pinigų sąjunga), bei diferencijuota integracija, kurioje nustatomos nuolatinès ribos tarp skirtingais laipsniais integruotų valstybių (pavyzdžiui, priklaususios ir nepriklaususios Vakarų Europos Sajungai šalys) ${ }^{4}$.

Kiekviena iš šių vizijų atspindėjo skirtingas politines nuostatas bei pasirengimą tolesnei integracijai. Beveik kiekvienas iš šių diferencijuotos integracijos metodų turejjo ir praktinius pavyzdžius, iš kurių dažniausiai minimi buvo pinigų sajunga, Šengeno susitarimas bei socialinè chartija. Vis dèlto dešimtmečio viduryje, rengiantis 1996-1997 m. tarpvyriausybinei konferencijai, vyraujančia diferencijuotos integracijos samprata tapo skirtingų greičiu Europa - glaudesnis bendradarbiavimas, kuriame skirtingu metu gali dalyvauti skirtingos valstybių narių grupès, tačiau jis turi būti atviras visoms kitoms šalims, be to, turi vykti vieningos ES institucinès struktūros ir vieningų taisyklių pagrindu. Kitaip sakant, tai vienu instituciniu ir teisiniu pagrindu besiremianti integracija, kurioje norų ir gebejimų integruotis skirtumai valdomi pereinamaisiais laikotarpiais (arba net jei pastarujų formaliai nèra, tikimasi, jog visos šalys anksčiau ar vėliau prisijungs prie naujų integracijos projektų). Šie glaudesnio bendradarbiavimo principai buvo $1997 \mathrm{~m}$. formalizuoti Amsterdamo sutartyje.

Prieš aptariant konkrečias šiuo metu ES sutartyje įtvirtintas glaudesnio bendradarbiavimo nuostatas, reikia pastebėti, jog diskusijos dél Amsterdamo sutarties nuostatų keliomis aplinkybėmis skyrėsi nuo ankstesnių tokio pobūdžio diskusijų $\mathrm{ES}^{5}$. Pirma, kaip minèta, tuo metu jau praktiškai buvo pradèta ịgyvendinti pinigu sajunga, kurios projektas numatė galimybę dalyvauti ne visoms šalims (tiesa, kai kurie Prancūzijos ir Vokietijos politikai tikèjosi, jog joje dalyvausianti valstybių nariu grupe neviršys šešių šalių, tačiau galutiniame sajungos kūrimo etape 1999 m. ji padidèjo iki vienuolikos). Antra, po kelių naujų narių prièmimo dalis jų arba nuolatos skeptiškai vertindavo naujus integracijos gilinimo projektus (Didžioji Britanija, Danija), arba nesugebėdavo juose dalyvauti (Graikija). Trečia, užsienio ir saugumo, o vèliau ir gynybos politikos klausimų iškèlimas ES bei dviejų tarpvyriausybinio bendradarbiavimo ramsčių sukūrimas Maastrichto sutartimi paskatino diskusijas apie naują ES vaidmenį saugumo srityje. Ketvirta, būsimoji ES (ir NATO) plètra, daugelio manymu, stiprino būtinybę numatyti išaugsiančios ịvairovẻs valdymo glaudesnio bendradarbiavimo priemonėmis metodus. Galiausiai susirūpinimas sienų apsauga (savo ruožtu susijęs ir su būsima plètra) taip pat prisidejo prie glaudesnio bendradarbiavimo klausimo iškèlimo ị tarpvyriausybinę darbotvarkę. Tad nors anksčiau dèl vienokių ar kitokių aplinkybių EB vis iškildavo diferencijuotos integracijos klausimas, tačiau būtent praẻjusio dešimtmečio viduryje susidariusių aplinkybių visuma sukūrẻ sąlygas jo įtraukimui ị tarpvyriausybinès konferencijos darbotvarkę ir pačią ES sutarti.

\footnotetext{
${ }^{4}$ Plačiau apie tai žr. Stubb A. A., „Categorization of Differentiated Integration“, Journal of Common Market Studies, vol. 34, No. 2, July 1996, p. 283-295; Warleigh A., Flexible Integration. Which Model for the European Union, London: Sheffield Academic Press, 2002, p. 9-13.

${ }^{5}$ Wallace, (note 4) p. 177.
} 


\section{Glaudesnio bendradarbiavimo nuostatos}

Nuostatos dèl glaudesnio (tuo metu vadinto ,artimesniu“) bendradarbiavimo i ES sutartị buvo ịtraukos 1997 m. Amsterdame (15-17 str.) bei 2000 m. šiek tiek modifikuotos Nicos sutartyje (43-45 str. ir keletas specifinių nuostatų, susijusių su konkrečiomis funkcinėmis sritimis). Beje, viena iš dažniausiai nurodomų šių ES sutarčių pataisų priežasčių buvo poreikis pritaikyti ES institucijas jos funkcionavimui po naujųų narių prièmimo. Glaudesnio bendradarbiavimo tema taip pat buvo gana plačiai diskutuojama ir pradejus diskusiją dèl Europos ateities bei svarstant konvente rengiamą ES konstituciją. Pavyzdžiui, šiai diskusijai neformalią pradžią suteikusioje Vokietijos užsienio reikalų ministro J. Fischer kalboje vienu iš svarbiausių akcentų buvo keleto labiausiai tolesnei integracijai pritariančių valstybių narių branduolys, turintis tapti avangardu, galiausiai politinès integracijos būdu paversiančiu ES federacine sistema ${ }^{6}$. Tačiau, nors galiausiai Konvento pateiktame ES konstitucijos variante glaudesnio bendradarbiavimo nuostatos buvo dar šiek tiek pakeistos, suprastinant esamas formuluotes bei pasiūlant keletą procedūrinių pakeitimų (bei pakeičiant glaudesnio bendradarbiavimo nuostatas saugumo ir gynybos srityje), svarbiausi jų bruožai išliko nepakitę ${ }^{7}$. Toliau, apžvelgiant šiuos pokyčius, pristatomos pagrindinès glaudesnio bendradarbiavimo nuostatos.

Pagrindinė glaudesnio bendradarbiavimo paskirtis yra ES tikslų igyvendinimas ir jos interesų apsauga. Pastebėtina, jog tik Nicos sutartyje ši nuostata buvo papildyta ir dar vienu glaudesnio bendradarbiavimo naudojimo pagrindimu - integracijos proceso sustiprinimu. Ši nauja nuostata išliko ir ES konstitucijos projekte. Ši nuostata atspindi Prancūzijos, Vokietijos ir kitų EB sukūrusių valstybių politikų populiarų požiūrị i Europos integraciją kaip ị savaime vertingą ir tęstiną procesą (o ne į priemonę kitiems tikslams igyvendinti).

Viena iš svarbiausių glaudesnio bendradarbiavimo sąlygų yra pagarba ES institucinei sąrangai ir teisiniam pagrindui. Amsterdamo sutartyje buvo numatyta, jog glaudesnis bendradarbiavimas gali būti naudojamas tik kaip kraštutinė priemoné, kai tam tikri ES tikslai negali būti pasiekti ịprastomis procedūromis. Ši nuostata, nors ir kiek pakoreguota, išliko ir ES konstitucijos projekte. İ lankstesnę buvo pakeista sąlyga dẻl minimalaus dalyvaujančių valstybių skaičiaus. Nicos sutartyje buvo atsisakyta pirminès nuostatos, kad glaudesnio bendradarbiavimo projektuose turi dalyvauti dauguma valstybių narių. Ji Nicos sutartyje buvo pakeista į minimalų aštuonių šalių skaičių (kuris ir yra dauguma iš penkiolikos narių, tačiau po plètros tai pasikeis), o ES konstitucijos projekte yra numatyta, kad tokiuose projektuose dalyvaus bent trečdalis visų valstybių narių (taigi ES-25 tai būtų aštuonios šalys). Nicos sutartyje taip pat buvo sušvelninti reikalavimai glaudesnei integracijos iniciatyvai

\footnotetext{
${ }^{6}$ Žr. Fischer J., „From Confederacy to Federation: Thoughts on the Finality of European Integration“ in Speech at the Humbodlt University in Berlin, 12 May 2000. I ši siūlymą netrukus neigiamai sureagavo ne tik kai kurie kitų Europos šalių atstovai, bet ir Fischer viziją vertinę akademikai. Žr. Zielonka J., Enlargement and the finality of European integration, Symposium: Responses to Joschka Fischer, Jean Monnet working paper, (7) 2000.

${ }^{7}$ Pakeitimai su paaiškinimais yra pateikti Konvento darbiniame dokumente: The European Convention Praesidium, Enhanced cooperation, Brussels, 14 May 2003, CONV 723/03.
} 
patvirtinti - tam dabar reikia tik kvalifikuotos daugumos balsų Ministrų Taryboje (išskyrus užsienio ir saugumo politiką, kur tokioms iniciatyvoms turi pritarti visos ES valstybės narès, tačiau šioje srityje, rengiant ES konstituciją, buvo numatyti pakeitimai, palengvinantys glaudesnio bendradarbiavimo inicijavimą).

Po ES sutarties modifikacijų išlieka dar viena svarbi glaudaus bendradarbiavimo sąlyga - jis gali būti naudojamas tik tose srityse, kurios nepriklauso išimtinei ES kompetencijai (taigi jis negalimas pinigų sajungos, išorès prekybos politikos ir žuvininkystės srityse). ES sutartyje kol kas taip pat numatyta, jog glaudesnis bendradarbiavimas neturi pažeisti vidaus rinkos, iškreipti prekybos ir konkurencijos tarp valstybių narių. Jis taip pat neturi paliesti Šengeno sutarties taisyklių. Tačiau pastarujų išlygų ES konstitucijoje siūloma atsisakyti.

Galiausiai dar viena svarbi glaudaus bendradarbiavimo sąlyga, išlikusi nuo Amsterdamo sutarties pataisų, - glaudaus bendradarbiavimo projektai turi būti visada atviri bet kuriai dalyvauti norinčiai valstybei narei. Tiesa, ES konstitucijos projekte (III-213 str.) numato ir detalias sprendimu prièmimo procedūras plètojant glaudesni bendradarbiavimo gynybos srityje (pavyzdžiui, dèl vẻliau prie grupès norinčios prisijungti narės galimybiu joje dalyvauti sprendžia tos grupės valstybės). Be to, visos ES valstybės narés gali dalyvauti glaudesnị bendradarbiavimą pradejusios šalių grupés diskusijose, tačiau nepriklausančios šiai grupei negali balsuoti priimant sprendimus šioje srityje. Priimti sprendimai yra privalomi taip pat tik grupei priklausančioms šalims. ES konstitucijos projekte taip pat numatyta, jog glaudesnio bendradarbiavimo metu priimtas acquis nèra privalomas ES šalims kandidatėms. Sprendimai grupès viduje gali būti priimami ir kvalifikuotos daugumos, ir vienbalsiu balsavimu, priklausomai nuo bendradarbiavimo srities, o balsai skaičiuojami remiantis tais pačiais principais, tik tarp grupès narių. Beje, po Amsterdamo sutarties nuostatų patvirtinimo kai kurie analitikai teige, jog tokioms šalims, kaip Prancūzija ir Vokietija, glaudesnio bendradarbiavimo projektų inicijavimas gali tapti bandymu pasididinti savo galią Ministrų Taryboje, kuri sumažès ES po plètros vien dèl to, jog išaugs narių ir jų turimų balsų skaičius ${ }^{8}$.

Tad galima teigti, kad, nepaisant ịvairių pasiūlymų, kuriuos per diskusijos dèl Europos ateities kẻlè ir ES valstybių politikai, ir ekspertai, glaudesnio bendradarbiavimo sąlygos išliko nelabai pakitusios ir atspindi kompromisą tarp besirūpinančiu tolesnès integracijos perspektyvomis ir siekiančių, kad bandymai kurti naujas grupes ES viduje nevirstų nuolatiniais skirtingų narystès statusų įtvirtinimu. Tad kyla klausimas, ar toks kompromisas ir po ES plètros tenkins valstybes nares, kiek juo gali būti naudojamasi ir kokia tikimybė, kad kai kurios valstybės narès (ypač Prancūzija ir Vokietija, į kurių siūlymą dèl glaudesnio bendradarbiavimo gynybos srityje buvo iš dalies atsižvelgta ES konstitucijos sutartyje) bus linkusios inicijuoti naujus integracijos projektus, kurie nepateks nei ị iprastinio, nei i glaudaus bendradarbiavimo rèmus. Šie klausimai savo ruožtu yra susiję ir su tuo, kiek ši plètra pakeis ES tarpvyriausybinio bendradarbiavimo principus ir neformalią koalicijų kūrimo dinamiką ir kiek dèl to atsiradusios naujos kliūtys ir galimybės skatins kai kurias šalis apeiti ịprastus bendradarbiavimo metodus (inicijuoti naujus projektus už ES ribų).

${ }^{8}$ De Areilza, (note 3 ). 
Prieš pereinant prie šiu klausimų aptarimo, reikia pastebèti ir dar vieną glaudaus bendradarbiavimo praktikos (ar jos trūkumo) ypatumą. Kol kas glaudaus bendradarbiavimo procedūros formaliai nebuvo nẻ karto panaudotos ES. Tačiau siūlymų šią procedūrą naudoti pastaraisiais metais būta ne vienas. Pavyzdžiui, pastaruoju metu Europos Komisija yra užsiminusi apie šios procedūros naudojimą, priimant kai kurias naujas aplinkosaugos taisykles, dèl kurių jau seniai nesutaria valstybès narès. Apie glaudesnį bendradarbiavimą užsimenama ir kalbant apie naujas iniciatyvas saugumo ir gynybos politikos bei mokesčių srityse.

Tokiais atvejais glaudaus bendradarbiavimo perspektyva veikia kaip papildoma paskata svyruojančioms šalims prisidèti prie naujų iniciatyvų ir pritarti Europos Komisijos siūlymams. Kitaip sakant, glaudaus bendradarbiavimo procedūra naudojama kaip savotiškas derybinis ịrankis stumtelti abejojančius ar nepritariančius tolesnés integracijos link. Kaip pastebi kai kurie analitikai, maždaug pusè iš visų tokiu atvejų, kai Europos Komisija ar ES pirmininkaujanti šalis panaudojo „grasinimą“ inicijuoti glaudesnị bendradarbiavimą, baigèsi tuo, jog nepritariančios sprendimui šalys pakeite savo nuomonę ${ }^{9}$. Būtent kaip „glaudesnio bendradarbiavimo šešèlis“ ši procedūra gali būti dažniausiai naudojama ir ateityje, jei susidariusi dauguma būtụ nepakankama sprendimams priimti. Beje, ES konstitucijos projekte siūlomas kvalifikuotos daugumos balsavimo taisyklès išplètimas ị naujas sritis bei jo supaprastinimas, labiau susiejant daugumos nustatymą su gyventojų skaičiumi, lyg ir turètų sumažinti poreikị naudoti glaudesnį bendradarbiavimą, kaip ES efektyvumą didinančią priemonę.

\section{Bendradarbiavimas didesnèje, ịvairesnèje, gausesnèje ES}

Nors teiginiai apie didesnę ir ịvairesnę ES po naujų narių prièmimo bei su tuo susijusị poreikị reformuoti Sajungos institucijas ir procedūras jau seniai yra tapę konvencine išmintimi, tačiau savaime šie teiginiai mažai ką pasako apie ES plètros poveikị tarpvyriausybiniam bendradarbiavimui tarp gausesnio valstybių narių būrio. Atsargiai žiürèti ị prognozes apie subyrèsiančią ES arba ị radikaliai pasikeitusị jos funkcionavimą reikètų dèl kelių priežasčiu. Dažnai tie, kas garsiausiai nuogąstauja dèl pasikeitusios ES, siekia pasinaudoti ES plètra savo politinès darbotvarkès tikslams ịgyvendinti (tarp jų gali būti ir ES pertvarkymas pagal federacinị modelị). Be to, kaip pastebi Wallace, JAV funkcionuoja ir būdamos penkiasdešimties valstijų federacija $^{10}$.

Tad nors didesnis klubo narių skaičius ir apsunkina koordinavimą bei padidina sutarimų paieškos kainą (ir netiesiogine - ilgesnio laiko - prasme, ir tiesiogine didesnio poreikio „nupirkti“ nepritariančių šaliu paramą didesnių išmokų iš ES fondų - forma), tačiau savaime didesnis valstybių narių skaičius nebūtinai tampa

${ }^{9}$ Phillippart E., Optimising the Mechanism for „Enhanced Cooperation“ within the EU: Recommendations for the Constitutional Treaty, CEPS Policy Brief, No. 33, May 2003. Autorius mini tokius atvejus kaip Europos bendroves statuto patvirtinimas, Europos arešto taisyklių suderinimas bei energijos mokestis.

${ }^{10}$ Wallace, (note 4 ). 
institucine ir procedūrine problema. ES funkcionalumui ir ịprastoms bendradarbiavimo procedūroms problema gali tapti ne didesnis valstybių skaičius, bet interesų (nacionalinių preferencijų) įvairove ir ypač skirtumai tarp labiau ir mažiau entuziastingai tolesnę integraciją palaikančių šalių. Kitaip sakant, ar senas klausimas apie tai, ką ES naremis esančių šalių grupė nori daryti kartu, paaštrẻs tiek, kad kai kurioms šalims patraukliausia bendrų integracijos projektų forma taps grupės narių skaičiaus sumažinimas (ir drauge jos dalyvių galios padidinimas) ar net naujų integracijos projektų inicijavimas už ES ribų.

Atsakymas ị tai priklauso nuo būsimų valstybių narių preferencijų suderinamumo ir jų galimų preferencijų išsiskyrimo atvejų. Tarptautinių santykių teorija pateikia keletą požiūrių i nacionalinių interesų (preferencijų) apibréžimo veiksnius, kuriuos galima išskirti i dvi grupes priklausomai nuo to, ar pirmenybẻ skiriama tarptautinèms struktūroms, ar vidaus politikos veikejjams. Struktūras akcentuojantys požiūriai (neorealizmas, institucionalizmas) pabrèžia ilgalaikes tarptautines struktūras bei valstybių bruožus, kurie apibrěžia jų vietą tarptautinèje bendrijoje. Liberalios tarptautinių santykių teorijos akcentuoja vidaus politikos veikejjų - interesų grupių, politinio elito, ekspertų ir jų sąveikos - reikšmę valstybinių preferencijų susiformavimui. Absoliuti dauguma Europos integraciją aiškinančių politinės ekonomijos požiūrių, pavyzdžiui, neofunkcionalizmas ar liberalusis tarpvyriausybiškumas, taip pat pripažista vidaus politikos veikejjų vaidmenị (ir didesnị ar mažesnį vaidmenị suteikia viršvalstybinems institucijoms, kurios, kai kurių analitikų nuomone, gali daryti ilgalaiki poveikị nacionalinèms preferencijoms) ${ }^{11}$.

Siame straipsnyje bus aptarta keletas struktūrinių ir ị vidaus politikos veikejjus orientuotų nacionalines preferencijas sąlygojančiu veiksnių bei aptartos galimos tarpvyriausybinès koalicijos ES po jos plètros pagal kiekvieną iš jų. Aptariamų veiksnių sąrašas nėra išsamus, juo tik norima iliustruoti galimas koalicijas ir jų sudètis. Priklausomai nuo to, kokios (didelès ar mažos, ilgalaikès ar trumpalaikès, sutampančios ar nepersidengiančios narių atžvilgiu) koalicijos tikètinos pagal skirtingus valstybių narių nacionalinių interesų pjūvius, galima prognozuoti ir glaudesnio bendradarbiavimo perspektyvas bei Lietuvos vietą tarpvyriausybinėse koalicijose.

Pagal valstybių charakteristikas tarptautinëje sistemoje galima išskirti keletą bruožų, dažnai lemiančių valstybių nacionalines preferencijas: tai valstybès dydis, geografinè vieta, istorinè patirtis bei ekonominio išsivystymo lygis. Kokios galimos tarpvyriausybinès koalicijos ES po jos plètros pagal kiekvieną iš šių valstybės bruožų?

Koalicijos pagal valstybių dydį ES susiformuoja tik institucinių reformų metu, kadangi reformuojant institucijas visada iškyla klausimas dẻl valstybių atstovavimo ES institucijose ir jų svorio priimant sprendimus. Kitaip sakant, institucinių reformų metu iškyla klausimas dèl valstybių narių santykinès įtakos ES politikai įtvirtinimo, kuris nusistovi iki kitų institucinių reformų. Būtent dẻl ilgalaikių institucinių reformų pasekmių valstybių santykinei formaliai galiai bei galimų skirtingų balsų svėrimo kriterijų (proporcingumo gyventojų skaičiui), tokių reformų metu ES valstybès

${ }^{11}$ Tiesa, pavyzdžiui, Moravcsik nuomone, nors valstybių preferencijų formavimuisi didžiausią poveiki daro ekonominių interesu grupių sąveika su vyriausybe, tačiau tarpvyriausybiniu derybų metu valstybės derybinę galią lemia jos ekonominių ryšių (a)simetrijos. Dẻl to, jo požiūriu, derybose didelès valstybės lemia daugiau nei mažos (žr. svarbiausią jo veikalą Moravcsik A., The Choice for Europe, Ithaca, NY: Cornell University Press, 1998.). 
narès paprastai pasidalina į mažų ir didelių šalių grupes. Tai buvo aiškiai pastebima paskutiniosios tarpvyriausybinès konferencijos, kuri parengė Nicos sutartị, metu. Tokia takoskyra išryškejjo ir šiuo metu Konvente bei rengiantis naujai tarpvyriausybinei konferencijai.

Paprastai institucinių reformų metu balsavimo taisyklių ir valstybių atstovavimo klausimais panašią poziciją atstovauja Vokietija, Prancūzija ir Didžioji Britanija. Kartais prie jų prisijungia ir Italija bei Ispanija. Tuo tarpu visos kitos valstybés, kurios yra vadinamos vidutinėmis ir mažomis, paprastai palaikomos Europos Komisijos, sudaro „mažujų koaliciją“. Vienas iš pagrindinių šios ES plètros bruožų yra mažų valstybių narių skaičiaus padidejjimas. Taigi, kaip jau galima pastebėti iš vykstančių diskusijų dẻl ES konstitucijos projekto nuostatų, jau dabar susidare mažų valstybių blokas, prie kurio prisijungusi ir Lenkija (bei Ispanija), kurios nenori Nicos metu joms numatytų balsų perdalijimo. Tiesa, šiam neformaliam blokui nepriklauso Beniliukso šalys, pasisakančios už siūlomus institucinius pakeitimus (Europos Komisijos skaičiaus ribojimą bei ES pirmininkavimo taisyklių pakeitimus), siejant tai su lūkesčiais, jog jie sustiprins tolesnę integraciją.

Pastebètina, jog institucinių reformų klausimu Prancūzija ir Vokietija, nepaisant šiek tiek skirtingų nuostatų dẻl ES federalizavimo, $2002 \mathrm{~m}$. antroje pusejje suformavo bendrą poziciją, kurios nemažai siülymų pateko ir į Konvento parengtą ES konstitucijos variantą (kai kurių analitikų nuomone, ES konstitucija labiausiai atspindi Prancūzijos preferencijas) ${ }^{12}$. Keletą svarbiausių pakeitimų (dèl Europos Komisijos sudèties, ES pirmininkavimo principų bei kvalifikuotos daugumos taisyklių) ypač atsargiai vertina Lietuva ir kitos „mažos"valstybès. Tiesa, jei pasirinkimas tarpvyriausybinëje konferencijoje bus tarp šių nuostatų prièmimo ir pasiektų kompromisų peržiūros, gali būti, jog „mažujų koalicija praras bendrumą ir galiausiai priims ES konstitucijos projekto nuostatas, kadangi nè viena valstybè nenorès tapti tarpvyriausybinès konferencijos nesėkmingos pabaigos „kaltininke“. Apibendrinant galima pastebèti,jog mažų ir didelių valstybių koalicijos susidaro tik beveik išimtinai institucinių reformų metu, o jos vyksta ne dažnai (nors per pastarajį dešimtmetį tokių bandymų buvo kaip niekada daug). Be to, formaliai žiūrint, didžiujjų valstybių, pirmiausia Vokietijos ir Prancūzijos, balsų neužteks, kad būtų sudaryta kvalifikuota dauguma Ministrų Taryboje, kai joje bus atstovaujamos 25 ar daugiau šalių, todẻl sprendimų prièmimui joms reikès ir dalies mažesnių valstybių balsų. Siuo atžvilgiu dvigubos kvalifikuotos daugumos modelio pateikimą galima laikyti reikšmingu minètų šalių bandymu didinti didžiưjų šalių galią Ministrų Taryboje, kuris galètų padėti ateityje ne mažiau efektyviai igyvendinti jų interesus gausesnèje ir įvairesneje Sajungoje.

Kitas valstybiu preferencijas apibrěžiantis veiksnys yra geografine padetis. Ji svarbi keliais atžvilgiais, kuriais veikia šalių užsienio politikos prioritetus: ES pakraščių valstybès gali būti linkusios kelti i ES darbotvarkę bendradarbiavimo su kaimyninėmis ES nepriklausančiomis šalimis; taip pat ES viduje geografiškai artimos valstybės dėl natūraliụ priežasčiu gali būti linkusios plètoti bendras bendradarbiavimo iniciatyvas. Šis veiksnys yra glaudžiai susijęs ir su bendra istorine patirtimi,

\footnotetext{
${ }^{12}$ Guerot U., Hughes K., Lefebvre M., Egenhoff T., „France, Germany and the UK in the Convention. Common Interests or Pulling in Different Directions“, EPIN Working Paper No. 7, July 2003, p. 12.
} 
kadangi geografiškai artimos valstybės dažnai turi ir bendros istorinės patirties. Tai pasakytina apie geografiškai artimas Beniliukso šalis, kurios, dar prieš sukuriant Europos anglių ir plieno bendriją, sukūrè trišalę muitų sajungą. Panašią grupę ir ES viduje, ir kartu su jai nepriklausančiomis šalimis sudaro Skandinavijos valstybès. Beje, 2000 m. rudenị Skandinavijos šalių sudaryta „išminčių grupe “ pasiūlè šioms šalims suintensyvinti regionini bendradarbiavimą, formuojant bendrą poziciją, atsiŽvelgiant ị tokius pokyčius ES kaip euro zonos sukūrimas ir būsimoji jos plètra ${ }^{13}$.

Tikètina, jog dèl šių priežasčiu bendrą poziciją tokiais klausimais, kaip infrastruktūros projektai (keliai, elektros energijos tiltas), ES atstovaus ir Lenkija bei Lietuva. Šios šalys abi gali būti suinteresuotos ir intensyvesniais ES santykiais su kaimyninėmis jai nepriklausančiomis šalimis - Ukraina, Rusija ar (priklausomai nuo vidaus politinès padèties) Baltarusija. Tokios šalių grupès arba koalicijos gali ateityje konkuruoti dèl ES užsienio politikos prioritetų ir jiems ịgyvendinti skirtų lěšų: Pietų Europos šalys gali propaguoti glaudesnius ryšius su Lotynų Amerika ar Viduržemio jūros šalimis, Graikijos, Italijos, kai kurios Vidurio Europos šalys - su Balkanų valstybėmis, Lenkija, Baltijos šalys bei Skandinavijos valstybės - su Rusija. Beje, šiuo atžvilgiu Prancūzija ir Vokietija dažnai gali atsidurti skirtingose koalicijose - pirmoji labiau orientuota ị Pietus, antroji -ị Siaurę ir Rytus.

Geografinè padètis ir istorinè patirtis turi ir dar vieną ypatumą. Iš dalies dèl šių veiksnių - artumo Rusijai bei istorinès okupacijos patirties - (iš dalies dẻl valstybès dydžio ir karinių pajègų) naujosios ES narès yra linkusios labiau palaikyti artimus ryšius su JAV ir remti jos įtakos išlaikymą (bei NATO vaidmenị) Europoje, nei daugelis dabartinių valstybių narių. Tiesa, šiuo, kaip ir kitais preferencijų formavimosi pjūviais, nesusidarys dvi atskiros senujjų ir naujujų narių koalicijos (dabartiniai ES nariai prieš naujuosius), bet formuosis jų deriniai. Pavyzdžiui, artimesnių JAV valstybių narių koalicijai gali priklausyti dauguma naujųjų ES narių ir Didžioji Britanija (bei Ispanija ar Italija). Ši preferencijų išsiskyrimą tarp „transatlantu““ ir „,kontinentu“"ypač aiškiai parode ES bei stojančiụjų šalių palaikymas (ar jo trūkumas) JAV konflikto Irake metu. Ne mažiau iliustratyvi buvo ir Prancūzijos prezidento reakcija ị JAV palaikančiujų šalių poziciją. Šiuo atžvilgiu Prancūzija tebeturi senų aspiracijų jei ne būti atsvara JAV pasaulio politikoje, tai bent sukurti tokią grupinę Europos šalių atsvarą ${ }^{14}$.

Pastarasis Prancūzijos motyvas gali suvaidinti svarbų vaidmenị ir plètojant jau besiformuojančią neformalią koaliciją tarp Prancūzijos, Vokietijos, Belgijos ir Liuksemburgo dèl „gynybos sajungos“ kūrimo, kurios idèja buvo iškelta 2003 m. kovo mèn. Diskusijos apie glaudesnį bendradarbiavimą tarp nedidelès valstybių narių grupès gynybos srityje prasidejo jau anksčiau, ir čia taip pat svarbiausią vaidmenį kol kas vaidino atgijęs Prancūzijos ir Vokietijos „motoras“. Abi šalys po 2002 m. rinkimų Prancūzijoje, kurie baigè vadinamą ,kohabitacijos“ Prancūzijoje periodą, kai prezidentas ir Vyriausybė atstovavo skirtingoms partijoms, iškilmingai atnaujino Prancūzijos ir Vokietijos ,ašies“veiklą, pateikdamos bendrus siūlymus institucijų reformos, saugumo ir gynybos, teisingumo ir vidaus reikalų, ekonominès politikos bei ES plètros finansavimo klausimais. Tada šių šalių politikai nedviprasmiškai užsiminė apie

${ }^{13}$ Nordic Council to discuss enhanced cooperation, Euobserver, 09.10.2000, www.euobserver.com.

${ }^{14}$ Grabbe H., Shaken to the Core, Prospect, May 2003, p. 12-13. 
glaudesnio bendradarbiavimo plètojimą saugumo ir gynybos srityse, nors tai formaliai ir neatitinka dar galiojančios Nicos sutarties nuostatu, pagal kurias gynybos sričiai negali būti taikomos glaudesnio bendradarbiavimo procedūros.

Šios problemos sprendimas galimas dviem būdais: arba tokio projekto vykdymas už ES ribų, arba šių nuostatų pakeitimas, priimant ES konstituciją, kurio, atrodo, siekia Prancūzija ir Vokietija iš anksto prie ES konstitucijos pridedamoje deklaracijoje, siekdamos numatyti tokiame projekte dalyvausiančių šalių sąrašą ir numatant glaudesniam bendradarbiavimui kiek kitokias taisykles, kuriomis galima būtu riboti norinčiujų prisijungti galimybes. Beje, vykstant tarpvyriausybinei konferencijai 2003 m. rudenị, Prancūzija ir Vokietija pradejjo svarstyti dviejų šalių branduolio, kuriame būtų suvienyta saugumo ir gynybos politika, sukūrimą ES po jos plètros. Šis siūlymas, kuris buvo viešai aptariamas po to, kai Prancūzija atstovavo Vokietijai viename iš ES viršūnių susitikimų, skirtų gynybos politikai, nèra naujas ir buvo iškeltas dar maždaug prieš dešimtmetị ${ }^{15}$. Tada jị pristabde Prancūzija ir gali būti, jog dabar ši idejja taip pat veikiau naudojama kaip derybinè priemonè, norint paskatinti kai kurias šalis greičiau pritarti tarpvyriausybinejje konferencijoje svarstomam ES konstitucijos projektui. Tai patvirtina ir šios idejos viešo aptarimo laikas, ir panašios Vokietijos bei Prancūzijos užuominos dèl finansinių ir kitokių „,sankcijų“ ES konstitucijos prièmimą stabdančioms šalims. Tačiau, nors dabar glaudesnis bendradarbiavimas (beje, tarp mažesnio šalių skaičiaus, nei numato ES sutartis) greičiausiai naudojamas kaip strateginè kitų partnerių itikinimo priemonė, jis rodo ir potencialius entuziastingiausiai tolesnę integraciją palaikančių valstybių tvarkymosi su išaugusios ES ịvairove būdus.

Kita problema - ne tik noras, bet gebejimas plètoti glaudesnị bendradarbiavimą gynybos srityje. Pavyzdžiui, naujienos apie Belgijos ir Liuksemburgo dalyvavimą naujoje iniciatyvoje dẻl gynybos sajungoje sukẻlè nemažai pašaipių komentarų apie šiu šalių potencialų indèlị ị karines struktūras. Kitaip sakant, bet kokia tokio pobūdžio iniciatyva sunkiai įsivaizduojama be Didžiosios Britanijos, kuri iki pastarojo meto gana atsargiai žiūrejjo ị tai. Nors pastaraisiais metais Didžioji Britanija palankiau pradëjusi vertinti bendrų iniciatyvų plètojimą gynybos srityje, tačiau visada nuosekliai išlaikoma parama NATO vaidmens Europoje išlaikymui, kurio neturètų sumenkinti naujos ES iniciatyvos. Tačiau jei ši Didžiosios Britanijos pozicija pasikeistų (o pastaruoju metu pasirodè tikrų pozicijos kaitos ženklų), tai sukurtų nemažų dilemų Lietuvai ir kitoms naujosioms ES ir NATO narems ${ }^{16}$. Prancūzijos, Vokietijos ir kai kurių kitų ES šaliu glaudesnio bendradarbiavimo iniciatyva gynybos srityje turètų stiprų simbolinị ir politinị poveikị naujosioms šalims. Nedalyvaudamos šioje iniciatyvoje jos prarastų ir (bent formalią) dalyvavimo priimant sprendimus galimybę, kuri laikoma viena iš svarbiausių narystès ES privalumų, ir turètų pergalvoti savo dalyvavimo gynybos ir saugumo aljanse politiką.

${ }_{15}$ Core Franco-German Union considered, Euobserver, 13.11.2003, www.euobserver.com. ${ }^{16}$ Po paskutiniojo trišalio Prancūzijos, Vokietijos ir Britanijos vadovų susitikimo pasirodė pranešimai, jog visos trys šalys sutarè dèl to, kad ES turètų būti sukurti „,bendri gebéjimai planuoti ir vykdyti operacijas, nesinaudojant NATO ištekliais ir pajejgumais“. Taip pat buvo teigiama, jog ši iniciatyva, trijų šalių nuomone, turètų būti plètojama arba sutarus visoms 25 valstybėms narèms, arba, jei tai nepavyks, „suinteresuotų partnerių rate“ (UK comes nearer to Franco-German position on defence//euobserver, 2003.09.23, www.euobserver.com). Tiesa, vėliau Didžiosios Britanijos vyriausybe paneigè pranešimus apie jos paramą tokiai iniciatyvai. 
Galiausiai dar vienas svarbus valstybių požymis, galintis lemti tarpvyriausybinių koalicijų formavimąsi ES po plètros, yra jų ekonominio išsivystymo lygis. Stojančiųų šalių pajamos vienam gyventojui, Eurostat duomenimis, 2002 m. sudare apie $40 \%$ ES vidurkio. Ir nors kai kurios naujosios narès (Slovenija) pagal šį rodikli jau aplenkusios kai kurias ES valstybes (Graikiją), o kitos auga sparčiausiai Europoje (Baltijos šalys), tačiau gana dideli ekonominių išsivystymų skirtumai tarp skirtingų valstybių narių išliks dar bent 15-20 metų. Tiesa, santykiniai skirtumai tarp valstybių narių turbūt niekada neišnyks, tačiau tikètinas jų sumažejimas ir, vykstant ekonominiam augimui, bendro ekonominio išsivystymo lygio ES didejjimas.

Tačiau kol ekonominiai skirtumai tarp šalių sumažès ir mažiau išsivysčiusios šalys taps turtingesnès, tikètinos gana skirtingos valstybiu pozicijos (ir koalicijos) tarp turtingesnių ir skurdesnių valstybių narių. Pozicijų skirtumai ypač ryškūs gali būti dviem aspektais - bendrujjų reguliavimo normų atžvilgiu bei perskirstymo per ES biudžetą klausimais. Didžioji dalis ES teisès normų yra skirtos prekybai tarp valstybių narių reguliuoti bei ,rinkos trūkumams“ taisyti, dažnai nustatant detalius produktų kokybės ar gamybos procesų standartus. Tas pats pasakytina ir apie harmonizuotus netiesioginius mokesčius (akcizą bei pridètinès vertès mokestį), kurių minimalios normos taip pat yra suderintos. Detalūs standartai, kurie dažniausiai atspindi turtingesnių šalių preferencijas, nors ir dažnai numatant pereinamuosius laikotarpius tam, kad palengvintu jų igyvendinimą skurdesnèse ES šalyse, reiškia didesnius prisitaikymo kaštus skurdesnių šalių įmonèms, biudžetams, vartotojams. Tai mažina jų konkurencingumą ir perskirsto pajamas. Būtent dèl šių normų igyvendinimo brangumo Lietuva ir kitos šalys susiderẻjo po porą dešimčių pereinamujjų laikotarpių derybose su ES.

Dabar daugelis ES darbotvarkèje esančių siūlymų yra susiję su griežtesnių reguliavimo normų (aplinkosaugos, chemijos produktų ir kitose srityse) diegimu. Tokių normų igyvendinimas turètų neigiamą poveikị Lietuvos įmonių konkurencingumui ir sąlygotų bent laikiną kainų augimą. Dèl tokių tikètinų pasekmių Lietuvos ir kitų stojančiujų šalių vyriausybės turètų sudaryti prieš griežtesnius privalomus standartus pasisakančiu šalių koaliciją (su sąlyga, jog vyriausybès neignoruos galimų griežtesnio reguliavimo pasekmių ar nepasiduos interesų grupių, kurioms tokios normos gali būti naudingos kaip apsauga nuo konkurentų įejjimo ị rinką). Apskritai po ES plètros dẻl joje išaugusių ekonominio išsivystymo skirtumų turètų būti priimama mažiau (ir léčiau) naujų reguliavimo normų. Tikètina, jog būtent dẻl to Europos Komisija pastaraisiais metais yra pateikusi nemažai siūlymų dèl lankstesnių reguliavimo metodų platesnio taikymo (rẻminių direktyvų, savireguliacijos ir kt.) ${ }^{17}$. Turbūt dèl to vienas pagrindinių naujųjų ES projektų - Lisabonos strategija - yra grindžiama atviro koordinavimo metodu, taip pat paliekančiu valstybėms narėms galimybes apsispręsti dèl tinkamiausių priemonių iškeltiems tikslams įgyvendinti.

Kitas su ekonominiu šalies išsivystymo lygiu susijęs koalicijų susidarymo aspektas - interesų sankirtos tarp į ES biudžetą daugiau sumokančių ir iš jo daugiau gaunančių šalių. Šiuo atžvilgiu galimos koalicijos tarp tokių šalių, kaip, viena vertus, Vokietija, Olandija ar Švedija, ir, kita vertus, daugumos kitų šalių, daugiau gaunan-

${ }^{17}$ Žr. Commission of the EC, „European Governance“, $A$ White Paper, Brussels, COM (2001) 428 , 25.07.2001. 
čių, nei sumokančiu i i ES biudžetą. Pastarojoje grupeje turbūt būtu ir dauguma naujųjų valstybių narių. Tiesa, net ir šiuo klausimu, kuriuo labiausiai tikètinas pasidalinimas tarp senujų ir naujujjų ES narių, vis dèlto tikètinos „mišrios“ koalicijos, kadangi tokios šalys, kaip Italija, Prancūzija ar Ispanija, gali taip pat palaikyti siūlymus didinti ES biudžeto išlaidas (ar bent nepritarti jụ mažinimui). Kita vertus, pavyzdžiui, Slovènija ar Estija gali prisijungti prie Vokietijos vadovaujamų šalių grupès. Beje, būtent šiuo klausimu tikètinas didžiausias Vokietijos ir Prancūzijos pozicijų išsiskyrimas (nors jo laipsnis gali priklausyti ir nuo tolesnio stabilumo ir augimo pakto likimo, kurio nuostatų, ribojančių biudžeto deficitą, šiuo metu nesilaiko abi šalys). Aiškesnès koalicijos ES biudžeto klausimais susiformuos, prasidejjus diskusijoms dėl naujo ES finansinio periodo.

Nacionalinès preferencijos formuojasi veikiant ne tik struktūriniams veiksniams, bet ir šalių vidaus politikos veikejjams. Toliau aptariami du vidaus politikos veiksniai - interesų grupių preferencijos bei politinio elito ịsitikinimai, kurių analizė grindžiama ekonomikų struktūra ir viešai deklaruojamomis šalių vyriausybių pozicijomis. Pagal šiuos du veiksnius bus prognozuojamos tikètinos valstybių narių koalicijos po ES plètros.

Interesu grupiu preferencijos ir ju įtaka valstybés politikai priklauso nuo ju veiklos pobūdžio ir organizuotumo. Tiesa, ES daugialypio valdymo sistemoje atskirų šalių interesų grupès, ypač sukūrusios Europos asociacijas, turi ir kitus įtakos kanalus, kurie būna nukreipti tiesiogiai į ES institucijas (ypač Europos Komisiją). Tačiau dažnai išnaudojami ir nacionaliniai ir viršvalstybiniai įtakos kanalai, o nacionalinès valstybès ir toliau yra šalies vidaus politikos arenoje veikiamos interesų grupių. Todėl prasminga ir toliau vertinti sąveiką tarp šalies interesų grupių ir vyriausybès, nors ir atsižvelgiant ị tai, jog kartais (ir priklausomai nuo konkrečios srities, pavyzdžiui, saugumo ir gynybos politikoje) interesų grupių itaka būna minimali.

Detali valstybių narių interesų grupių preferencijų analizè išeina už šio straipsnio rẻmų. Čia apsiribojama keliais pastebẻjimais. Pirma, daugelis naujųjų šalių yra mažesnès ir santykinai atviros ekonomikos šalys. Atsižvelgiant ị užsienio prekybos dalị šalių BVP, tikètina, jog didelè dalis šiu šalių įmonių bus suinteresuotos kliūčių užsienio prekybai šalinimu. Tačiau, išskyrus keletą pereinamujų laikotarpių, tokios kliūtys turètų išnykti nuo narystės ES datos. Dèl šios priežasties ir dẻl gana glaudžiu ekonominių ryšių su kaimyninėmis ES nepriklausančiomis šalimis naujujų narių i̇monės gali palaikyti prekybos su trečiosiomis šalimis liberalizavimo politiką, o tai gali neatitikti kai kurių dabartinių ES valstybių narių tradiciškai saugumų sektorių interesų.

Vis dèlto tarptautinès prekybos pramonès gaminiais liberalizavimas Pasaulio prekybos organizacijos (PPO) derybose yra pažengęs gana toli ir šiuo metu daugiausia klausimų ir nesutarimų kelia prekyba žemės ūkio produktais (ir parama ūkininkams) bei netarifinių prekybos barjerų reguliavimas. Dèl žemés ūkio klausimų galima prognozuoti keletą tikètinų koalicijų, kurios sujungs, viena vertus, šalis su didele žemès ūkio dalimi ekonomikoje arba tradiciškai stipria ūkininkų įtaka, kita vertus, šalis, kuriose ūkininkai nėra įtakingi. Tikètina, jog pirmajai grupei priklausytų Prancūzija, Italija, Ispanija bei Lietuva, Rumunija, Lenkija, Latvija. Šios šalys turbūt atsargiai vertins ir tolesnius žingsnius Bendrosios žemès ūkio politikos reformos link bei 
derybas PPO dẻl prekybos žemės ūkio produktais liberalizavimo. Tiesa, gali būti, jog dèl nustatytų diskriminacinių tiesioginès paramos sąlygų naujosios narès gali palaikyti paramos ES ūkininkams mažinimą vien tam, kad sumažintų paramos skirtumus senosiose ir naujosiose narèse. Tačiau išnykus diskriminacijai šie motyvai taip pat išnyks ir pagrindiniais dẻl ūkininkų spaudimo taps kuo didesnès paramos ūkininkams užtikrinimas.

Netarifinių kliūčių prekybai šalinimo srityje pagrindinis klausimas ES vidaus rinkoje bus tolesnis bendrų reguliavimo normų diegimas. Kaip jau minèta anksčiau, vien dèl ekonominio išsivystymo lygio skirtumų griežtesnių standartų diegimas neigiamai veiktų naujųjų šalių įmonių konkurencingumą. Kita vertus, kaip iliustruoja pereinamieji laikotarpiai, kuriuos ES (valstybės narès) taikys kabotažo paslaugoms bei darbo jëgos judèjimui, kai kurios interesų grupès (profesinès sajungos, kai kurios sektorinès organizacijos) ieškos būdų apsisaugoti nuo vis dar pigesne darbo jëga grindžiamos konkurencijos iš naujųų šalių. Tiesa, šuo klausimu ne visada išsiskirs naujujų ir senuju narių pozicijos, kadangi turtingesnès naujos narès gali palaikyti Vokietiją ir Skandinavijos šalių poziciją, o kai kurios dabartinès valstybès narès (pavyzdžiui, Graikija) gali palaikyti už status quo reguliavimo srityje pasisakančias šalis.

Galiausiai, vertinant valstybių narių vyriausybių (politinio elito) preferencijas, galima išskirti porą klausimų. Tai arba už liberalizavimą, arba už valstybès ịtakos išlaikymą (didinimą) pasisakančiu šalių koalicijos. Kitas pjūvis - arba prieš, arba už tolesnę integraciją ES vien dèl „kuo glaudesnès Sajungos kūrimo“ pasisakančių valstybių narių koalicijos. Nors nuostatos valstybės (ir viršvalstybinių institucijų) vaidmens ekonomikoje atžvilgiu turètų priklausyti nuo partijų ideologijos, tačiau šiuo metu ES valstybèse narėse (ir stojančiose šalyse) galima pastebèti kiek kitokią tendenciją. Už ekonomikos liberalizavimą (ypač diskusijose apie Lisabonos strategijos igyvendinimą pasisako) Didžiosios Britanijos vyriausybė su Ispanijos vyriausybe, kartais dar palaikomos Italijos ir Portugalijos vyriausybių. Tikètina, jog, sprendžiant iš šalių pasisakymų konvento darbo metu, prie šios grupès iš naujujų narių tarpo prisijungs Estija bei Čekija.

Tuo tarpu prieš liberalizavimą ir dereguliavimą dažniausiai pasisako Prancūzija, kartais palaikoma Vokietijos (nors abiejose dèl demografinių ir fiskalinių priežasčių pastaruoju metu vyriausybės bando pradèti reformas) bei Austrijos ir Skandinavijos šalių (tiesa, pastarosios išsiskiria tuo, jog atstovauja liberaliam požiūriui diskusijose apie ES išorès prekybos politiką). Tikètina, jog prie šių skeptiškai tolesni liberalizavimą vertinančių šalių prisidès ir Lietuvos, Lenkijos bei daugelio kitų naujụjų narių vyriausybès. Tiesa, kai kuriose iš jų šiuo metu vykdoma užsienio prekybos politika yra liberalesnè nei ES, privatizacijos eiga pažengusi toliau nei kai kuriose ES valstybėse narėse. Tačiau tai yra veikiau pirmujų reformos metų sprendimų, kuriuos „užfiksavo“ insipareigojimai tarptautinèms finansinèms institucijoms bei prekybiniai susitarimai, o ne politinio elito ịsitikinimų rezultatas. Apskritai tolesnè socializacija ES institucijose bei Lisabonos strategijos, atspindinčios bandymus eiti „trečiuoju“ arba „Europietiškos socialinės rinkos“ keliu, igyvendinimas stiprins kompromisų paieškos kultūrą, o ne ideologiniais modeliais grindžiamą politiką. 


\section{Išvados}

İvertinus galimas tarpvyriausybines koalicijas ES po jos plètros pagal svarbiausius nacionalinių preferencijų formavimo veiksnius, galima pateikti keletą išvadų.

Pirma, menkai tikètinas nuolatinių dviejų koalicijų, iš kurių vienai priklausytụ tik naujosios ES valstybės narès, o kitai - tik dabar esančios narėms, egzistavimas. Tikètini įvairių koalicijų deriniai, kurių sudètis priklausys nuo konkretaus svarstomo klausimo. Tokią išvadą patvirtina ir kiti darbai, analizuojantys ES politiką po jos plètros $^{18}$. Tai mažina glaudaus bendradarbiavimo projektų tikimybę.

Antra, tarpvyriausybinių koalicijų dydis ir jų ilgalaikiškumas priklausys nuo svarstomų klausimų. Pavyzdžiui, mažų ir didelių valstybių narių koalicijos susidaro institucinių reformų metu. Turtingesnių ir skurdesnių valstybių narių koalicijos formuosis svarstant ES finansinès perspektyvos klausimus. Už ir prieš bendrają žemès ūkio politiką pasisakančių vyriausybių koalicijos susidarys svarstant šios politikos reformą (tai iš dalies susiję ir su ES biudžeto svarstymu). Bene pastoviausia koalicija, galinti peraugti i glaudesni bendradarbiavimą kai kuriose srityse, yra už tolesnę integraciją pasisakančių šalių grupé, kurią sudaro EEB sukūrusios šalys.

Trečia, koalicijų kaitos ir galimų nuolaidų, pateikiamų derybų metu, susiejant skirtingus ES darbotvarkès klausimus, atžvilgiu ES po plètros nelabai skirsis nuo ankstesnès ES. Nors derybų trukmę pailginti ir sprendimų paiešką komplikuoti gali didesnis valstybių narių skaičius, tačiau ES politinis procesas neturètų radikaliai pasikeisti po jos plètros. Tiesa, ilgesnè derybų trukmé (ypač tada, jei tarpininko vaidmens tinkamai negalès atlikti Europos Komisija ir neiškils aiškus lyderis, galintis tarpininkauti, skirtingus interesus turinčioms šalims) gali sulètinti sprendimų prièmimą ir šitaip sustiprinti paskatas naudoti glaudesnio bendradarbiavimo metodą. Šią tikimybę didina ir ta aplinkybė, jog anksčiau nepritariančiu tolesnei integracijai šaliu pritarimas dažnai būdavo pasiekiamas įvairiomis finansinèmis paskatomis (paprastai sukuriant naujas regioninès plètros programas), o dabar naujų finansavimo programų kūrimas ir ES biudžeto išlaidų didinimas yra menkai tikètinas. Tiesa, paskatas plètoti glaudesnį bendradarbiavimą gali sumažinti kvalifikuotos daugumos balsavimo taisyklių reforma ir lankstesnių reguliavimo metodų taikymas. Tačiau tose srityse, kur sprendimai bus priimami vienbalsiai, o preferencijos tolesnès integracijos atžvilgiu smarkiai skirsis, poreikis glaudesniam bendradarbiavimui gali išlikti.

Ketvirta, glaudesnio bendradarbiavimo tikimybe yra didžiausia saugumo ir gynybos politikos srityje. Ši sritis yra labiausiai atsieta nuo ekonominių klausimų, todèl sunkiau keistis ir nuolaidomis tarp saugumo ir gynybos politikos bei ekonominių klausimų (kiekvienoje iš šių sričių dominuoja skirtingi nacionalinių preferencijų formavimosi veiksniai ir motyvai - vienoje didesnị vaidmenị atlieka tarptautinè aplinka, kitoje - vidaus interesų grupès, ministrai dažnai mažiau žino apie vieni kitų reikalus nei, pavyzdžiui, finansų ir žemès ūkio ministrai ir pan.). Čia jau dabar išaiškẻjo galima iniciatyvinè valstybių narių grupè, nors ji kol kas yra perpus mažesné

${ }_{18}$ Žr. pavyzdžiui Moravcsik A., Vachudova M. A., 2002 National Interests, State Power and EU Enlargement // East European Politics and Society, August 2002, juodraštis; Baun, M. EU Intergovernmental Politics after Enlargement, Paper presented at the 8th Bieennial International Conference of the EUSA, Nashville, March 27-29, 2003. 
(keturios šalys), nei turètų būti, kad galètų formaliai pradėti glaudesnio bendradarbiavimo iniciatyvą. Be to, visos dabar joje norinčios dalyvauti šalys taip pat priklauso ir už gilesnę integraciją pasisakančių šalių grupei. Tiesa, šios iniciatyvos formalizavimui būtinas Didžiosios Britanijos dalyvavimas ir bent keleto kitų valstybių nariu prisijungimas. Tokia iniciatyva taip pat turètų būti suderinta su NATO. Galiausiai tam bus reikalingos papildomos léšos, kurias visuomenei pagrịsti ekonominio sąstingio metu yra sunku.

Tikètina, jog artimiausiu metu po ES plètros glaudesnio bendradarbiavimo galimybė bus dar dažniau naudojama kaip kitų šalių itikinimo priemonè, o ne alternatyvus sprendimų priẻmimo mechanizmas, padedantis valdyti augančią interesų ịvairovę ES. Daugiausia naujų integracijos iniciatyvų kils neformaliose senųjų valstybių nariu grupèse, ypač tarp EB sukūrusių valstybių, kurios formalizuodamos ir keldamos naujas iniciatyvas į ES politinę darbotvarkę glaudesnio bendradarbiavimo perspektyvą naudos kaip derybinę priemonę. Ar kai kurios iš šių iniciatyvų iš tiesų pavirs glaudesnio bendradarbiavimo projektais, priklausys nuo jas inicijuojančiu šaliụ interesų stiprumo bei susilaikančių šalių nenoro prisidèti prie siūlomo projekto. ES, kurioje tikètinos lanksčios nuo konkretaus klausimo priklausančios koalicijos ir kurioje sprendimai bus priimami supaprastintos kvalifikuotos daugumos balsavimo taisyklių pagrindu, glaudaus bendradarbiavimo iniciatyvos neturètų būti dažnos.

Galiausiai, jei glaudaus bendradarbiavimo iniciatyvos ES būtų iš tiesų igyvendamos, kokias pasekmes jos turètų Lietuvai? Atsakymas ị šį klausimą priklauso nuo glaudesnio bendradarbiavimo vaidmens integracijos procese vertinimo. Glaudesnis bendradarbiavimas gali būti naudingas ir už jo ribų liekančioms šalims (jei tokia būtų Lietuva), kadangi jis leidžia geriau suderinti skirtingas preferencijas, neišardant ES ir derinant įvairovę su esamais integracijos pasiekimais, ypač vieningos rinkos funkcionavimu. Tiesa, Lietuvai glaudesnio bendradarbiavimo iniciatyvos nekeltu grèsmès, jei jos išliktų atviros kitoms šalims. Tačiau tokios iniciatyvos sukurtų nuolatinị spaudimą - ir jei jos būtų naudojamos tik kaip derybinès priemonès, ir jei jos būtų praktiškai ịgyvendinamos. Šis spaudimas kiltų iš sudètingos dilemos, pasirenkant tarp nacionalinių interesų ir tarp noro būti integracijos avangarde bei dalyvauti vien dèl to, kad būtų galima apsisaugoti nuo paribio statuso. Sprendžiant šią dilemą, svarbiausia bus tinkamai ivertinti Lietuvos interesus Sajungoje ir pasirinkti partnerius. Tačiau reikia pripažinti, jog išaugusi interesų įvairovė neišvengiamai sukurs situacijas, kai reikès rinktis arba tarp harmonizavimo (kuriame daugiausia turbūt lems didžiujų ir turtingujų valstybių preferencijos), arba tarp glaudesnio bendradarbiavimo, kuriame Lietuva nedalyvautų, arba lankstaus bendradarbiavimo formų (atviro koordinavimo metodo) naudojimo. 